the word 'spleenwort' is spelt in three different ways. It is a pity that in this article, and indeed in all the other articles, the generic and specific names are printed in the same Roman type as the rest of the text. Other articles recording some excellent fieldwork include hover-flies by $R$. Underwood, the birds of Arkholme by A. N. Gardner, the molluses of Port Erin (I.O.M.) by P. Brindley, and British mountain scenery by F. D. Stell. Other articles include the meteorological summary for June 1953May 1954 by J. I. Sharp, a description of making prints of leaves, etc., on photographic paper by A. M. Till, trout by G. Smith, collecting bees, wasps, etc., by T. H. Pennington, some observations of Amoeba by $P$. F. Williams, and $a$ short description of giant tadpoles by G. H. Briggs.

\section{Corrosion Technology}

Starting in March this year, Corrosion Technology was published as a supplement to Chemical and Process Engineering, and from June it has appeared as a separate monthly journal, published by Leonard Hill, Ltd., of London (1, No. 4; June 1954. 40s. a year, or $100 s$. for 3 years). There are now, therefore, two monthly journals devoted to the subject of corrosion, the other being Corrosion Prevention and Control (see Nature, May 8, p. 853). Corrosion Technology carries three columns to a page, 12 in. by 9 in. The journal includes many useful items of news concerning developments in methods of preventing corrosion, in addition to the technical articles by various authorities. These include one on "Corrosion in relation to Welding", by Dr. U. R. Evans, of Cambridge ; others deal with the corrosion resistance of welded stainless steel, paint versus corrosion, cathodic protection, corrosion research at the Chemical Research Laboratory, Teddington, rubber linings to protect plant in a new bromine factory, prevention of corrosion by water in oil refineries, non-metallic materials of construction for handling radioactive wastes, radioactive testing of rust preventives, corrosion of aluminium cable sheathing, cutting fluids and corrosion, and corrosion and tablet machinery. The variety of the topics reflects the wide range of the subject of corrosion. The journal is well produced, and it serves a useful purpose in providing corrosion workers, as well as engineers and others concerned with protection against corrosion, with up-to-date news and reviews of recent developments in the subject.

\section{Periodicals in South Asia on the Physical and Biological Sciences}

WiтH the assistance of the United Nations Educational, Scientific and Cultural Organization, the Indian Library Association has now published Vol. I, covering the physical and biological sciences, of a "Union Catalogue of Learned Periodical Publications in South Asia" (pp. 390. Delhi : Indian Library Association; London: George Blunt and Sons. Rs. 25,9 dollars or $60 s$. ; 1953). It is essentially the work of the Department of Library Science of the University of Delhi, and its publication represents the partial fulfilment of an aspiration of Dr. S. R. Ranganathan, the principal editor, twenty-five years ago; all the collaborators are past or present students of his. The Catalogue covers 175 libraries in India and 74 in Indonesia, Malaya, Burma and Ceylon. It consists of a Systematic Catalogue, arranged according to the Colon Classification, and indicating the status or subject of specialization of the library, as well as the holdings, and of an alphabetical index, in which title words of periodicals are given in heavy type. There is also a schedule of sub-classes of the Colon Classification covered and a key to library numbers. The Catalogue should prove of great assistance to research workers in South Asia.

\section{Society for General Microbology}

ThE Society for General Microbiology has recently undergone some reorganization and has established a central office at the Institute of Biology, 'Tavistock House South, Tavistock Square, London, W.C.1, to which inquiries regarding applications for membership and payment of subseriptions should in future be directed. Other matters should be communicated to the appropriate officer of the Society, and inquiries about the Journal of General Microbiology to the Cambridge University Press. At the last annual general meeting a new set of rules of the Society was passed, which now govern its activities. The nineteenth general meeting is to be held in the University of Reading during September 14-16 and is to include a discussion meeting on the "Principles of Microbial Classification". New officers of the Society are as follows: General Secretary, Prof. K. E. Cooper (Department of Preventive Medicine, University of Bristol) ; and New Members of Committee, Dr. B. W. Lacey, Miss June Lascelles and Dr. P. Tate. The remaining officers are : President, Mr. H. J. Bunker ; Treasurer, Prof. R. Lovell ; Editors of the Journal, Prof. B. C. J. G. Knight and Mr. A. F. B. Standfast; and Meetings Secretary, Dr. E. F. Gale (Department of Biochemistry, University of Cambridge).

\section{Biology of the Trout}

Regular observations have been made by the Scottish Home Office Brown Trout Research Laboratory, near Pitlochry in Perthshire, on freshwater biology in that area. Under the title of "Spawning Migration, Reproduction and Young Stages of Loch Trout (Salmo trutta L.)", Mr. T. A. Stuart has now recorded the results of research on the behaviour, reproduction and development of trout in their natural spawning grounds in three lochs, Lochan an Daim, Dunalastair Reservoir and Loch Moraig (Freshwater and Salmon Fisheries Research, No. 5. Pp. 40. Edinburgh: H.M.S.O., 1953; 7s. 6d. net). While the gonads appear to ripen at approximately the same time each year, the dates of spawning are influenced by the temperature. Prior to the spawning migration, a shoaling habit is formed and the trout congregate at the entrance to the streams chosen for spawning. Shoaling was only in evidence when the temperature of the loch water dropped to about $9^{\circ} \mathrm{C}$. The main spawning run took place when the temperature of the streams dropped for the first time to 6-7 $7^{\circ} \mathrm{C}$. and was lower than that of the loch. In his observations on the trout's behaviour in forming the redd, Mr. Stuart has made the notable discovery that, apart from selection of gravel of suitable size, appreciation of the current conditions plays a most important part. He has shown that towards the tail-ends of pools, where the gravel slopes upwards, there is a point at which the current flows downwards through the gravel and keeps it free of silt. The trout are evidently aware of this and, after testing movements, come to rest there, probably aided by the slight suction from below. At such points the redds are made. Further interesting observations are recorded on the reactions of the alevins to light, the ventilation of redds by the 